Hodkinson, P. (2009) 'Spectacular Youth? Young People's Fashion and Style, in Furlong, A. (ed.) Handbook of Youth and Young Adulthood, London: Routledge.

\title{
Spectacular Youth? Young People's Fashion and Style
}

\section{Paul Hodkinson}

The ways young people use clothing and other forms of bodily decoration as a means of expressing themselves has been an important focus for researchers of youth culture. There is a degree of agreement among scholars that style offers a means for adolescents to explore and express identity within a transitory period of the life course in which the dependencies of childhood gradually are relinquished without yet having fully been replaced by adult routines and responsibilities. Yet the details of how and why style is used and how this should be theorised and understood are the subject of considerable debate. This chapter outlines key elements of such debates, beginning with the influential work of a well known group of theorists from Birmingham, UK and developing a number of points of discussion which continue to dominate contemporary research of the subject.

\section{Spectacular style cultures}

The most well known body of research on youth and style was provided by the University of Birmingham's Centre for Contemporary Cultural Studies (CCCS) in the 1970s. Focusing on the 'spectacular' fashions associated with subcultures such as teds, mods, skinheads, bikers and punks, the CCCS writers interpreted youth style as an expression of collective identity and defiance. Against the context of the partial decline of traditional working class communities and the rise of rock ' $n$ ' roll and youth consumerism, it was argued that the visual uniforms of style subcultures represented a temporary or 'magical' solution to the confused and subordinated position of working class young people (P. Cohen 1972). In the first instance, the adoption such styles was argued to offer individuals a strong, defiant source of belonging during a time of uncertainty and, in placing emphasis on this, the CCCS drew upon subcultural theories emanating from US sociology (e.g. A. Cohen 1955). Yet the explanation of the neo-Marxist CCCS writers signalled a more specific role of style with respect to youth and social class. The adoption of collective stylistic uniforms was deemed simultaneously to represent firstly an expression of youthful difference from the traditional working class culture of their parents and secondly a new stylistic form of class defiance against dominant bourgeois values (P. Cohen 1972; J. Clarke et al 1976).

Of importance to this notion of style as resistance is the CCCS' understanding of the relationship between subcultures and the world of media and commerce. Although clearly linked to an embrace of consumer goods, it was argued that, rather than being 'bought off the shelf' or imitated from mass media, subcultural styles had emerged through the creative assembly by young people of a range of disparate items into 
coherent ensembles. Everyday items of clothing and other goods were selected, appropriated and, through their combination, assigned new subcultural meanings. The scooter, for example, was transformed by mods from an 'ultra respectable means of transport' into 'a weapon and a symbol of solidarity' (Hebdige 1976: 93), while the humble, functional safety pin became a symbolically important piece of jewellery within punk style. Having been thus assembled, each style was understood to perform a slightly different form of class resistance. The skinhead style, with its emphasis on traditional masculinity, was regarded as an attempt to stylistically reclaim a working class community in decline (J. Clarke 1976). Meanwhile, mods, it was claimed, were engaged in a stylistic parody of bourgeois values through appropriating a range of ultra-smart garments and combining them with scooters, pills and a hedonistic, rebellious lifestyle (Hebdige 1976).

Yet, for all their emphasis on fashion as an active, resistant form of youth expression, the CCCS' account also underlines the increasing power and influence of large scale commerce over youth cultural styles. Not only are there occasional references to a 'conventional' culture, whose stylistic choices presumably were assumed to be dictated by media, but it is also suggested that resistant subcultural styles eventually would be exploited by fashion and music industries, stripped of their subversive meanings and sold back to broader sections of the population as packaged products (Hebdige 1976; 1979). Stylistic resistance, according to this view, could only ever be temporary.

The CCCS have proved enormously important to academic discussions about youth and style and their approach has generated points of contention which continue to dominate contemporary research agendas. In the following pages, we'll examine some of these.

\section{Social Background or Individual Choice?}

According to the CCCS, the style of subcultures was not a matter of individual preference or coincidence, but a grassroots reaction to the situation of being young and working class in post-war Britain. Yet others question whether we should understand young people's styles as an expression of class or indeed other fixed elements of social context. Some suggest the Marxist leanings of CCCS prompted them to assume subcultural styles were attributable to class without providing empirical evidence of their demographic make-up or of the processes through which the groups emerged and recruited members (G. Clarke 1981). A related problem is that, whilst John Clarke and colleagues recognised that 'the great majority of working class youth never enters a tight or coherent subculture' (1976: 16), they were unable fully to explain what it was that prompted a minority to become involved in subcultures, while most of those who shared their class background did not. The implication is that other, more individually-specific factors must have played a role and that to explain stylistic choices purely as a response to class is over-simplistic.

Yet even if the CCCS' understanding of the link between youth style and social class background was justified, many argue that, as a result of social change, people's identities, tastes and lifestyles have since become less directly connected with the social status into which they were born. According to this view, previously significant 
markers of one's place in the world, including class, religion and locality, have become less influential, while the expansion and diversification of media and leisure industries has encouraged individuals to develop personalised consumer identities (Bauman 2001). And if such changes are indeed taking place, then it is perhaps logical to suggest that adolescents - already renowned for occupying an unstable and transitory period of life - may experience disconnection from traditional social categories particularly acutely. Thus, Muggleton (2000), Bennett (1999) and others argue that we should understand contemporary youth style not as an automatic response to social position but as a complex set of choices made by each individual. Rather than being locked into particular forms of stylistic expression as a result of their background, then, young people continually piece together their own identities.

Yet few would argue that traditional social categories have become entirely irrelevant to youth cultural expressions. Studies have repeatedly demonstrated complex but clear connections between ethnicity and particular forms of cultural expression (Nayak 2003; Huq 2006). Gender too remains of the utmost significance to young people's uses of style, with either dominant expectations or reactions to them comprising a key element of both majority and minority styles (Holland 2004; Harris 2007). Some research also suggests that social class retains significance. Thornton illustrates that the denigration within rave culture of 'mainstream' clubbers through the stereotype of 'Sharon and Tracy dancing around their handbags' reflected elitist assumptions relating to both gender and class (1995). More recently, Shildrick shows that class and neighbourhood remained strong predictors of youth style within the poor estates she studied, in which a clearly identifiable 'tracker' style was virtually ubiquitous (Shildrick 2006).

\section{Group Styles or Individual Difference?}

Another criticism of the CCCS is that they over-simplified the groups they examined, focusing on exclusive ideal-type group styles rather than on individual diversity or movement between groups (Clarke 1981). Observation of the recent expansion in the range of commercial styles on offer to consumers has prompted severe doubts over whether contemporary youth styles coalesce into neat subcultural affiliations. Rather, it is suggested that each individual compiles their own ensemble from the range of disparate items on offer and, in so doing, may draw from and cross-cut various genres or types. It follows that, rather than being fixed, individual styles and the DIY identities to which they are linked will fluctuate and change as young people develop their identities (Polhemous 1997). According to Muggleton, even those whose appearance resembles that of an identifiable subculture are at pains to emphasise selfexpression and individual difference rather than group commitment (2000). The notion of the subcultural group is deemed to imply a set of collective restrictions which young people reject in favour of a 'fragmented, heterogenous and individualistic stylistic identification' (2000: 158).

For some, this elective, individualistic use of fashion and style renders the notion of subculture less useful in understanding such matters than another term, 'neo-tribe'. Drawn from the social theory of Maffesoli (1996), neo-tribe refers to groupings which offer an emotional attachment but whose boundaries are porous and whose membership is transitory: 'it is less a question of belonging... than of switching from 
one group to another' (1996: 76). For Bennett, this emphasis on partial, temporary attachment to loose stylistic amalgams makes neo-tribe particularly suited to the cultural consumption practices of contemporary youth (1999).

Others, meanwhile, have criticised the specific tendency for subcultural theory to focus disproportionate attention on unusually spectacular or deviant youngsters (Laughey 2006). Studies of female youth cultural activities played an important role in the development of studies of 'ordinary' youth. Criticising the marginalisation of female youth within the work of their CCCS colleagues, McRobbie and Garber emphasised the prevalence among 1970s teenage girls of comparatively non-deviant indoor activities such as reading teen magazines and experimenting with clothes, makeup and hair (1976). The study of everyday fashion among young women has since developed into a significant body or literature which, amongst other things, has addressed the negotiation of youth with media representations of femininity. Other studies of 'ordinary' youth style include Willis' examination of the creative consumption practices of 'common culture' (1990) and Laughey's research on young people's everyday uses of music (2006). In contrast to previous emphasis on youth culture as a means of collective differentiation from parents, Laughey suggests that parents and siblings form significant components of individually unique portfolios of influence.

Yet the extent of the rejection of collective youth practices in individualistic "postsubcultural' theories is regarded as unhelpful by some. Hesmondhalgh acknowledges that 'the CCCS subculturalists may at times have over-estimated the boundedness and permanence of... group identities' but rejects Bennett's implication that 'relations between taste and identity are pretty much... dependent on the whims of individuals' (2007: 40; also see Blackman 2005). Meanwhile, recent group-oriented studies have continued to demonstrate the significance of collective style identities. Whilst outlining many of the complexities of club culture, Thornton identifies a clear set of collective standards through which clubbers both emphasised their collective difference from those outside their scene and judged and classified one another (1995). An emphasis on collective values also pervades Hodkinson's study of goths, which also illustrates the visual distinctiveness and consistency of the goth style, the strength of many participants' commitment to the group and a degree of separation between the subculture's networks and those of other groups (2002). Both studies retain the use of subculture as descriptor for the groups in question, even though they are critical of some elements of the CCCS' use of the term.

\section{Creative Resistance or Media Manipulation?}

A further area of contention pervading studies of youth culture since the 1970s is the extent to which young people's use of style may be regarded as active, or even subversive. As we have seen, the CCCS studies tended to assert that subcultural styles were assembled in a creative and autonomous fashion and that they communicated a youthful form of class resistance. The notion of youth style as an active and subversive form of consumption which defies the marketing of mainstream media and commerce and/or challenges dominant values has since been developed by others. Willis (1990) argues that elements of subversive creativity comparable to those previously identified in subcultures could also be observed in the stylistic 
consumption practices of broad sections of 'ordinary' youth. Such consumption was deemed to involve extensive knowledge, selectivity and imagination, reflecting grassroots interactions among friendship groups as much as the influence of media. As with the CCCS studies, the culture industries are relegated here to provider of raw materials, with young people themselves afforded the role of stylistic creators.

Studies focused upon gender and sexuality, meanwhile, have discussed a number of examples of the apparent challenging of dominant assumptions through style. Gotlieb and Wald (1994), for example, emphasise the subversive aspects of Riot Grrl style, in which participants and performers parodied the sexualisation of women and the aggressive assertion of male sexuality within the rock industry. Overtly sexual clothing was combined with the aggressive deployment of the body and even the appropriation and adornment on the body of derogatory terms such as 'slut'. Meanwhile, both Siegel (2006) and Brill (2007) explore the implications of the apparent gender ambiguity on display within goth style, in which both males and females adopt a dark, feminine blend of clothing, jewellery and makeup. However, while Siegel concludes that goth style represents a form of gender resistance, Brill suggests that, in spite of challenging some conventions, the goth scene retains many dominant assumptions about masculinity, femininity and heterosexuality.

A key criticism of the CCCS, which also is applicable to some more recent studies such as Siegel's, is that the notion of style as resistance was in most cases based, not on an analysis of the views of those young people involved but on the external interpretation of the content of youth styles by academic 'experts'. Such an approach entails an assumption either that the interpretation of the critic is shared by those involved or that the subjective understandings of participants are unimportant. Acknowledging that many subculturalists would not have recognised themselves in his interpretations of their activities, Hebdige (1979) apparently opts for the latter view and alongside it an implication that youth styles acquire an external subversive significance independent of the motivations of their creators. Many researchers view such bypassing of the experiences of young people as problematic and, as a consequence, recent studies of youth and style often have adopted participant-centred approaches, characterised by interviews and often a combination of participation and observation.

A further objection to proclamations about the resistant qualities of youth style is that they sometimes can underestimate the influence of media and commerce. The ongoing diversification of culture industries arguably makes it increasingly unlikely that new styles or subcultures could emerge purely on the basis of youth spontaneity. Through the employment of 'cool hunters' amongst other tactics, commercial organisations seek to latch onto, publicise and exploit new styles before they even have been fully conceived. Meanwhile, youth media regularly construct and publicise new styles as an effective means to increase circulation and sell advertising space (Thornton 1995; Osgerby 2004). Rather than consisting of active appropriations, then, some suggest that even the most marginal of youth styles revolve around a form of niche marketing; they are, for the most part, bought off the shelf. From this point of view the attribution of resistance to young people's uses of style - whether within spectacular subcultures or more ordinary contexts - may be dangerously complacent, constituting an uncritical endorsement of consumerism as the solution to social and cultural problems. 


\section{Conclusion}

Starting with the studies of spectacular subcultures carried out by the CCCS, this chapter has explored key issues in the study of youth and style, including the relationship between style and social background, the extent to which style is collective or individualised and debates about whether youth style can active or resistant. In spite of the disagreements relating to these and other themes, the notion of youthful style as response to the particular transitional circumstances of adolescence is broadly accepted. Yet in recent years, the categories of youth and youth culture in many societies have themselves become a little more ambiguous, with greater numbers of people retaining 'youthful' styles and pursuits well beyond the traditional age categories associated with adolescence. Rather than being a shortlived 'phase' it seems that some of the stylistic and behavioural features once regarded as the preserve of 16-25 year olds are in fact becoming prevalent across a broader age range (Bennett 2007). A key focal point for future scholarship, then, is to establish what exactly we mean by youth style and what it is that substantially differentiates the practices and motivations of late teens from those of older consumers engaging in apparently similar activities.

\section{References}

Bauman, Z. (2001) The Individualized Society, London: Polity.

Bennett, A. (1999), 'Subcultures or Neo-Tribes? Rethinking the Relationship Between Youth, Style and Musical Taste', Sociology 33(3): 599-617.

Bennett, A. (2007), 'As Young As You Feel: Youth as a Discursive Construct', in Hodkinson, P. and Deicke, W. (eds.), Youth Cultures: Scenes, Subcultures and Tribes, New York: Routledge.

Blackman, S. (2005), 'Youth Subcultural Theory: A Critical Engagement With the Concept, its Origins and Politics, from the Chicago School to Post Modernism', Journal of Youth Studies, 2005: 1-21.

Brill, D. (2007), 'Gender, Status and Subcultural Capital in the Goth Scene', in Hodkinson, P. and Deicke, W. (eds.), Youth Cultures: Scenes, Subcultures and Tribes, New York: Routledge

Clarke, G. (1981), 'Defending Ski-Jumpers: A Critique of Theories of Youth Subcultures', in S. Frith and A. Goodwin (eds) (1990), On Record: Rock, Pop and the Written Word, London: Routledge.

Clarke, J., Hall, S., Jefferson, T. and Roberts, B. (1976), 'Subcultures, Cultures and Class: A Theoretical Overview', in S. Hall and T. Jefferson (eds), Resistance Through Rituals: Youth Cultures in Post-War Britain, London: Hutchinson. 
Cohen, Albert (1955), Delinquent Boys: The Culture of the Gang, London: CollierMacmillan.

Cohen, P. (1972), 'Subcultural Conflict and Working Class Community', Working Papers in Cultural Studies, 2: 5-70.

Gotlieb, J. and Wald, G. (1994), 'Smells like teen spirit: Riot grrrls, revolution and women in independent rock', in A. Ross and T. Rose (eds.), Microphone fiends: Youth music \& youth culture, New York: Routledge, 250-274.

Harris, A. (ed.) (2007), Next Wave Cultures: Feminism, Subcultures, Activism, London: Routledge.

Hebdige, D. (1976), 'The Meaning of Mod', in S. Hall and T. Jefferson (eds), Resistance Through Rituals: Youth Subcultures in Post-War Britain, London: Hutchinson.

Hebdige, D. (1979), Subculture: The Meaning of Style, London: Methuen.

Hesmondhalgh, D. (2007), 'Recent Concepts in Youth Cultural Studies: Critical Reflections From the Sociology of Music', in Hodkinson, P. and Deicke, W. (eds.), Youth Cultures: Scenes, Subcultures and Tribes, New York: Routledge.

Hodkinson, P. (2002), Goth: Identity, Style and Subculture, Oxford: Berg.

Holland, S. (2004), Alternative Femininities: Body Age and Identity, Oxford: Berg.

Huq, R. (2006), Beyond Subculture: Pop, Youth and Identity in a Postcolonial World, London: Routledge.

Laughey, D. (2006), Music and Youth Culture, Edinburgh: Edinburgh University Press.

Maffesoli, M. (1996), The Time of the Tribes: The Decline of Individualism in Mass Society, London: Sage.

McRobbie, A. and Garber, J. (1977), 'Girls and Subcultures: An Exploration', in S. Hall and T. Jefferson (eds), Resistance Through Rituals: Youth Subcultures in PostWar Britain, London: Hutchinson.

Muggleton, D. (2000), Inside Subculture: The Postmodern Meaning of Style, Oxford: Berg.

Nayak, A. (2003), Race, Place and Globalization: Youth Cultures in a Changing World, Oxford: Berg.

Osgerby, B. (2004), Youth Media, London: Routledge. 
Polhemous, T. (1997), 'In the Supermarket of Style', in S. Redhead (ed.), The Club Cultures Reader, Oxford: Blackwell.

Shildrick, T. (2006), 'Youth Culture, Subculture and the Importance of Neighbourhood', YOUNG, 14 (1).

Siegel, C. (2006), Goth's Dark Empire, Indianapolis: Indianna University Press.

Thornton, S. (1995), Club Cultures: Music, Media and Subcultural Capital, Cambridge: Polity.

Willis, P. (1990), Common Culture: Symbolic work at Play in the Everyday Cultures of the Young, Milton Keynes: Open University Press. 